\title{
The role of the emotional intelligence in the relationship between medical personnel and the patient
}

\author{
Nicoleta CHICU \\ The Bucharest University of Economic Studies, Bucharest, Romania \\ chicu_nicoleta@yahoo.com \\ Alecxandrina DEACONU \\ The Bucharest University of Economic Studies, Bucharest, Romania \\ alecxandrinadeaconu@gmail.com \\ Lavinia RASCA \\ The Institute for Business Administration in Bucharest, Bucharest, Romania \\ laviniar@asebuss.ro
}

\begin{abstract}
The way we recognize and manage emotions, empathy, stress management, and the ability to build harmonious relationships, or emotional intelligence, are little explored in the medical field, although they have been shown to play a very important role in recovering patients and increasing the degree of their satisfaction with the accessed medical services. The purpose of the research is to highlight, based on the results of an investigation, whether the emotional intelligence of medical staff influences the quality of the medical services offered and patients' satisfaction. Towards this end, the authors performed a survey based on the emotional intelligence test developed by Daniel Goleman and presented in his book "Emotional Intelligence", and modified and adapted by Mihaela Roco. The patients included in the sample answered to a questionnaire related to their satisfaction when they used medical services.
\end{abstract}

Keywords: Emotional Intelligence, Medical Services, Patient Satisfaction

\section{Introduction}

The scientific and practical interest for emotional intelligence is obvious and explainable. The reality demonstrates that people benefit from knowing and mastering their emotions, from effectively decrypting and approaching the emotions of others, both in personal and professional relationships, and achieve success. Thus, emotional intelligence has become an important field of research in the domain of human resources, management, education, psychology, medicine.

\section{Literature review}

\subsection{Emotional intelligence and its components}

Emotional intelligence is based on the emotions that come from the limbic area of the brain. It determines individual's instinctive reaction to the world, the intelligence that originates in neocortex - the ability to learn, quickly and efficiently, to understand, to retrieve new information, to assimilate and to apply them efficiently and correctly.

The concept emotional intelligence was formulated for the first time in the United States by Wayne Leon Payne (1985), who considered emotional intelligence to imply a 
creative relationship with states of fear, pain and desire (Roco, 2004), and later, (1990), Emotional Intelligence, an article published in a scientific magazine, by John Mayer and Peter Salovey who were trying to develop a scientific method for measuring emotions that make people different. They have discovered that some people are more skilled in identifying their own feelings, the feelings of others, and in solving emotional problems. Due to these findings, authors Mayer and Salovey are recognized as the creators of the theory of emotional intelligence.

Moreover, emotional intelligence is associated with the name of Daniel Goleman (1995). Due to his work, emotional intelligence has become one of the most debated concepts in the States United States of America, defining the connections between emotions and thoughts, between feelings and action, and representing the individual's ability to wisely manage emotions. Emotional intelligence means being aware of both own emotions and those in relation to the others, by identifying and understanding them, and also by knowing how to use them. Using and managing emotions is a dynamic process, each ability influencing and interacting with the other (Bratianu \& Orzea, 2013; Hasson, 2016). Daniel Goleman states that we have two minds, one emotional and one rational, which often act in close harmony and balance. The links between the amygdala nucleus and the neocortex are the center of struggles or agreements of mind and soul, of thoughts and feelings, explaining why emotions are so important for effective thinking both in making wise decisions and in clear thinking (Goleman, 2008). Goleman (1998) defines emotional intelligence as being able to recognize both our own feelings and the feelings of others, to motivate us, to effectively manage our emotions in relationship with oneself or with others. Emotional intelligence facilitates discrimination between them, and uses information to control some situations or actions (Salovey \& Mayer, 1990). People need emotional intelligence to identify and effectively manage own emotions regarding personal goals (in career, family, education) with minimal inter and intrapersonal conflicts. Other authors (Deaconu, Podgoreanu, \& Rasca, 2004) describe emotional intelligence as the ability to feel, understand and effectively apply the power of emotions as a source of energy, information, creativity, trust and networking.

After 30 years of research on brain function, Richard Davidson (Davidson \& Begley, 2016) demonstrates the connection between the brain and the emotions, explaining that each person has the own emotional style, governed by specific networks, identifiable and measurable by objective laboratory methods, a style that has a certain pattern of brain activity and has six dimensions: attention, perspective, resilience, self-awareness, context sensitivity, and social intuition. Together, they determine what we call emotional intelligence, and the diverse ways in which they are combined explain why each person responds differently to life events. Our brain is designed to be emotional, so the first reaction to an event will always be emotional, impossible to be controlled; only the following emotions and the way we react to them can be controlled. For changing brain patterns and for improving emotional responses, one must first learn to identify, understand, and define emotions. There were more scientists and researchers who studied facial expressions, including Charles Darwin, who stated that the expressions generated by emotions are universal, and the ability to recognize the emotions of those around with precision is essential not only for success and happiness, but even for survival (Darwin, 1998). Paul Ekman (1993) issued a theory of emotions that included a set of basic emotions 
such as anger, fear, happiness, sadness, surprise, and disgust, generated by interpersonal actions.

Other researchers have created their own models, one of the most accurate being that of Plutchnik, who proposed eight primary emotions grouped on a positive or negative basis: joy to sadness, anger to fear, confidence to distrust, surprise to anticipation. Some basic emotions can be altered to form complex emotions. There are relationships between basic emotions, resulting in positive or negative influences (Plutchik, 1994).

Some basic emotions described by researchers are presented in the table below:

Table 1.1: Basic emotions

\begin{tabular}{|l|l|l|l|}
\hline PLUTCHNIK & EKMAN & TOMKINS & IZARD \\
\hline Joy & Happiness & Fun & Joy \\
Trust & Excitement & Fear & Fear \\
Fear & Tender & Surprise & Surprise \\
Surprise & Fear & Affliction & Affliction \\
Sadness & Angrer & Disgust & Anger \\
Disgust & Sadness & Anger & Disgust \\
Anger & & \\
Anticipation & & Interest & \\
& & Shame & \\
\hline
\end{tabular}

According to numerous studies, there are more independent types of intelligence, each operating as a separate brain system, with own rules: cognitive intelligence measured by the intellectual IQ (index of the level of intelligence development, determined by the reporting of the mental age at the chronological age); emotional intelligence, measured by the EQ; spiritual intelligence or SQ, a rather vague concept that is quite difficult to explain, however very well connected with the other two, especially with EQ. They determine personality, the "style" that defines each person as a result of preferences, and which is stable over life. We can use personality to develop emotional intelligence, but the latter does not depend on the former. Cognitive (academic) intelligence, emotional intelligence and spiritual intelligence are considered pure types of intelligence (Bradberry \& Greaves, 2016).

One of the researchers who tried to classify intelligences and develop the traditional conception of intelligence was Howard Gardner, the so-called parent of the Multiple Intelligence Model, author of Frames of Mind (1983). Gardner believes that there is no general factor to give intelligence a unitary value, rather there are some essential, independent mental capacities that underlie emotional intelligence, which he calls multiple intelligences (Gardner, 1993) (Table 1.2.) 
Table 1.2: Multiple intelligences

\begin{tabular}{|l|l|}
\hline Visual-spatial intelligence & the ability to visually perceive what surrounds us \\
\hline Verbal -linguistic intelligence & the ability to use words and to speak \\
\hline Mathematical-logical intelligence & the ability to use reason, logic and numbers \\
\hline Kinesthetic intelligence & $\begin{array}{l}\text { the ability to control body movements and skill in } \\
\text { working with different objects }\end{array}$ \\
\hline Musical intelligence & the ability to produce and appreciate music \\
\hline Interpersonal intelligence & the ability to understand and relate to others \\
\hline Intrapersonal intelligence & $\begin{array}{l}\text { the ability to self-reflect and to become aware of my } \\
\text { own self }\end{array}$ \\
\hline Naturalist intelligence & the ability to understand nature, to help keep it \\
\hline
\end{tabular}

Emotional intelligence is exemplified by three distinct models, each with its own set of tests and indices:

1. The model of Peter Salovey and John Mayer (Caruso \& Salovey, 2012) that first introduced this concept in 1990 - defining emotional intelligence as the ability to sensitize and control emotions. For them, emotional intelligence combines feelings and thinking and consists of four abilities that together can provide us with success in life: identifying the experiences of others, using emotions to improve our thinking, understanding the causes of emotions, integrating and managing emotions in decision-making.

2. Dr Reuven Bar-On created (Reuven, 2007) his own model on emotional intelligence, which contains an EQ-I test for assessing emotional intelligence. Reuven BarOn presents another version of emotional intelligence grouped into the following components: Intrapersonal aspect - awareness of own emotions that involves experiencing the present and not the past, assertiveness, self-respect, self-reliance, independence; Interpersonal aspect - empathy, interpersonal relationships, social responsibility; Adaptability - problem solving, reality testing, flexibility, change management; Stress control - stress tolerance, emotional management; General provision - happiness and optimism. Within the emotional intelligence, according to the two authors above, capacities are included in five areas: auto control, empathy, self-knowledge, motivation, social competencies.

3. The model of Daniel Goleman, who was interested to study the brain, creativity and behavior (Goleman, McKee, Boyatzis, 2007) includes four dimensions: self-awareness, social awareness, relationship management, and self-management. The understanding of the causes of emotions, the integration and management of emotions lead to better decisions.

Based on newly discovered data about emotions and the brain, a new field has emerged: affective neuroscience, evolving and modeling views on the dimensions and skills of emotional intelligence. Thus, Goleman simplified the original model of five domains and 25 competencies of emotional intelligence, retaining only four areas: self-knowledge, selfmastery, social consciousness; relationship management and 18 competences: personal skills (skills that relate to the way we deal with ourselves), and social skills (skills that relate to the way we handle our relationships), as shown in Table 1.3: 
Table 1.3: Areas of emotional intelligence and adjacent skills

\begin{tabular}{|c|c|}
\hline Self-competencies & Social competencies \\
\hline $\begin{array}{l}\text { Self-knowledge } \\
\text { emotional self-knowledge } \\
\text { correct self-evaluation } \\
\text { self-confidence }\end{array}$ & $\begin{array}{l}\text { Social awareness } \\
\text { empathy } \\
\text { organizational consciousness } \\
\text { solicitude }\end{array}$ \\
\hline $\begin{array}{l}\text { Self-control } \\
\text { emotional self-control } \\
\text { transparency } \\
\text { adaptability } \\
\text { ambition } \\
\text { initiative } \\
\text { optimism }\end{array}$ & $\begin{array}{l}\text { Relationship management } \\
\text { inspired leadership } \\
\text { influence } \\
\text { training others } \\
\text { catalyzing changes } \\
\text { dispute management } \\
\text { team spirit and collaboration }\end{array}$ \\
\hline
\end{tabular}

PICBE | 677

In time, other emerging models have evolved, which are illustrating the dynamics of this area of research. Most models of emotional intelligence are structured in these four generic areas: self-awareness, self-management, social consciousness, and relationship management (Goleman, 2016). In contrast, there is a disagreement related to the innate or acquired features of emotional intelligence, but it is nonetheless considered that, unlike the degree of cognitive intelligence (which once initiated remains constant throughout life), emotional intelligence components, can be taught. Thus, the degree of emotional intelligence can be enhanced through education and exercise (although some components of emotional intelligence are treated as personality traits, which are more difficult to change). The level of emotional intelligence is not genetically fixed and does not develop only in childhood. It continues to grow the whole life as a result of personal experience.

\subsection{The emotional intelligence and the medical services}

Daniel Goleman stated (Goleman, 2008) that EQ is sometimes more important than IQ, especially in humanistic fields, such as the medical one, where empathy and self-control are at least as important skills as those purely cognitive. In the world of affection, emotions are dominated by fear, because when people get sick, they become emotionally fragile, especially in the case of serious illnesses. People move from a fully secure mental state to one in which this illusion is shattered and feel weak, helpless and vulnerable.

The modern medical system seems to have long ignored emotional intelligence, although it is so important for prevention and rehabilitation, since it is demonstrated that emotions influence health, and connections between mind, emotions and body are recognized (Davidson \& Begley, 2016). Stress and negative emotions influence immune and cardiovascular system. They are major health risk factors that can make the body more prone to diabetes, heart disease and artery blockages (Goleman, 2016). The patients should be treated with medical care, emotional intervention being a basic component. Research on intensive care proves that another person's soothing presence has led to lower patient blood pressure and even reduced fatty acid secretion that blocks the arteries, lowering the risk of myocardial infarction (Goleman, 2016). 
Often medical staff in inpatient, indifferent to the emotional reality of the disease, forget the vulnerabilities of patients in the absence of time, focus on healing of the disease, rather than its bearing, are busy to record data in the computer, rather than pacifying them. Patients dislike the most the fact that physicians do not know to listen and talk to them. On the other hand, the inability of patients to ask questions about their situation is very common in clinics and hospitals. Studies show that patients waiting to enter the consultation have, on average, three questions to ask to the doctor, and leave consultation with an average of 1,5 answers. This reality leads to uncertainties, patients that fail to comply with the medical guidelines or adhere to them partially because they have not understood or have not carefully followed what the doctor has told them; about half of the prescribed drugs are never taken, and patients who follow the instructions are those who feel that the doctor is really concerned about their health (Goleman, 2014). Hospitals where patients' emotions are taken care of are more effective and efficient in their recovery.

\section{Research on the relationship between emotional intelligence and patient satisfaction, at Floreasca Emergency Hospital Bucureşti 2.1 Purpose and objective of the study}

Authors aimed to study the correlation between emotional intelligence demonstrated by the medical staff in their relations with the patients, and patients" satisfaction. They also studied how performance of the organization can become better, by improving these relations.

The main objectives of the research were:

o to research the emotional intelligence level of the medical staff from the Reconstructive Plastic Surgery and Microsurgery Clinic;

- to research how emotional intelligence of medical staff and patient satisfaction corelate and how to improve the performance of the medical staff.

\subsection{Research hypotheses, investigated sample and tools used}

Hypotheses:

1. The emotional intelligence of medical staff influences patient satisfaction.

2. The increased emotional intelligence of medical staff enhances the quality of medical services and consequently patients' confidence in medical services offered.

The sample consists of 25 physicians from the Clinic of Plastic Surgery and Reconstructive Microsurgery, and 25 patients admitted to this clinic. The sample of medical staff consisted in 36\% male and 64\% female; 7 of them aged 25-30 years, 13 aged 30-45 years, 4 aged 45-60, one was over 60 years old; 5 respondents were primary doctors, 5 specialist doctors, 7 resident doctors and 8 nurses; $92 \%$ of them worked in the organization for 10 to 40 years, and only $8 \%$ for less than 10 years. 
The 25 patients were $68 \%$ male and $32 \%$ female; 22 of them were over 40 years old, 2 between 18-25, one over 80; 9 had higher education, 11 secondary education, 5 were elementary school graduates.

\subsection{Tools used/Research projection/data collection}

For data collection, testing was performed under standard conditions, with 50 interview technique.

To analyze the level of emotional intelligence of the medical staff, the emotional intelligence test developed by Daniel Goleman (1995), and modified by Mihaela Roco (2004), was used.

The Emotional Intelligence questionnaire contained 10 situational questions. To interpret responses, a number of points to each answer were assigned, based on Goleman test. The scores were calculated, the meaning of the results being:

- up to $100 \mathrm{p}$ : below average;

- 100 p - 125 p: average score;

- 125 p - 175 p: above average;

- 200 p: exceptional.

The study presented a series of limitations:

- low availability of medical staff to respond to the questionnaire;

- refusal to participate in this research.

\section{Results and discussions}

The 10 dimensions of emotional intelligence analyzed using the test applied to medical staff were grouped according to their personal and social competencies.

Personal skills

Authors concluded that, as far as self-knowledge is concerned, all respondents have achieved the maximum score for awareness of personal emotions: medical assistants 160p, resident doctors 140p, primary doctors and specialists 100p. For the item "change propensity", minimum scores were obtained: nurses and primary doctors got $40 \mathrm{p}$, and doctors and residents $20 \mathrm{p}$. In terms of self-control: intrinsic motivation, optimism and the ability to engage in new situations / relationships, the most motivated are specialists and residents (80p), followed by nurses (60p), and the least motivated are primaries (40p). The most optimistic are the nurses (140p), the residents being the most pessimistic (40p). Residents have a high capacity to get involved in new situations (90p), like nurses (85p). Social skills

The points obtained for items that test social consciousness: empathy and support for others are as follows: the most empathic are resident doctors (110p), followed by 
nurses (75p), while primary and specialists have the lowest scores (35p). The most supportive were nurses (100p) and resident doctors (80p), unlike senior doctors who obtained (20p). It is best to control the aggressiveness of resident doctors (100p), unlike primary doctors $(20 \mathrm{p})$, specialist physicians have the greatest capacity to build relationships (60p), unlike residents (20p), and for diversity, all healthcare professionals obtained minimum scores, specialist doctors, residents and nurses (40p), while primary doctors (20p).

Table 3.1 shows emotional intelligence scores for each professional category, the total scores for each dimension of emotional intelligence, and the arithmetic average for the dimensions of emotional intelligence, along with the arithmetic mean of all medical staff. The value of 97.2 indicates that the emotional intelligence of the medical staff is below average.

Table 3.1 Sum of scores and averages obtained in the emotional intelligence test

\begin{tabular}{|c|c|c|c|c|c|c|}
\hline $\begin{array}{l}\text { IE } \\
\text { dimension }\end{array}$ & $\begin{array}{l}\text { Primary } \\
\text { doctors }\end{array}$ & $\begin{array}{l}\text { Specialists } \\
\text { doctors }\end{array}$ & $\begin{array}{l}\text { Resident } \\
\text { Doctors }\end{array}$ & Nurses & Total score & $\begin{array}{l}\text { Arithmetic } \\
\text { score }\end{array}$ \\
\hline $\begin{array}{l}\text { Awareness of } \\
\text { personal } \\
\text { emotions }\end{array}$ & 100 & 100 & 140 & 160 & 500 & 20 \\
\hline $\begin{array}{l}\text { Support for } \\
\text { others }\end{array}$ & 20 & 20 & 80 & 100 & 220 & 8.8 \\
\hline $\begin{array}{l}\text { Intrinsic } \\
\text { motivation }\end{array}$ & 40 & 80 & 80 & 60 & 260 & 10.4 \\
\hline Optimism & 60 & 60 & 40 & 140 & 300 & 12 \\
\hline $\begin{array}{l}\text { Openness to } \\
\text { diversity }\end{array}$ & 20 & 40 & 40 & 40 & 140 & 5.6 \\
\hline Empathy & 35 & 35 & 110 & 75 & 255 & 10.2 \\
\hline $\begin{array}{l}\text { Managing } \\
\text { aggression }\end{array}$ & 20 & 40 & 100 & 60 & 220 & 8.8 \\
\hline $\begin{array}{l}\text { Ability to } \\
\text { build new } \\
\text { relationship }\end{array}$ & 40 & 60 & 20 & 40 & 160 & 6.4 \\
\hline $\begin{array}{l}\text { Ability to get } \\
\text { involved in } \\
\text { new } \\
\text { situations }\end{array}$ & 35 & 45 & 90 & 80 & 255 & 10.2 \\
\hline $\begin{array}{l}\text { Availability } \\
\text { for change }\end{array}$ & 40 & 20 & 20 & 40 & 120 & 4.8 \\
\hline $\begin{array}{l}\text { IE score for } \\
\text { each } \\
\text { professional } \\
\text { category }\end{array}$ & 410 & 500 & 720 & 800 & 2430 & 97.2 \\
\hline $\begin{array}{l}\text { Quote the } \\
\text { emotional } \\
\text { intelligence } \\
\text { test }\end{array}$ & \multicolumn{6}{|c|}{$\begin{array}{l}\text { - up to } 100 \text { p: below average } \\
\text { - } 100 \text { p - } 125 \text { p: average score } \\
\text { - } 125 \text { p - } 175 \text { p: above average } \\
\text {-200p: exceptional }\end{array}$} \\
\hline
\end{tabular}

Source: author's contribution 
The research showed that patients were satisfied with the medical services offered by the hospital, with the involvement of doctors and nurses, as the average of the grades awarded was 4.30, as shown in Table 3.2:

Table 3.2 Average arithmetic patient satisfaction

\begin{tabular}{|l|l|l|l|}
\hline $\begin{array}{c}\text { Category of medical } \\
\text { services }\end{array}$ & \multicolumn{1}{|c|}{ Total score } & \multicolumn{1}{|c|}{ Arithmetic score } & \multicolumn{1}{|c|}{$\begin{array}{c}\text { Overall satisfaction } \\
\text { (Average) }\end{array}$} \\
\hline Hospitals & 106 & 4.24 & 4.30 \\
\hline Doctors & 107 & 4.28 & \\
\hline Nurses & 110 & 4.4 & \\
\hline \hline \multicolumn{2}{|l}{ Marks accorded to medical services and medical } \\
staff & $\begin{array}{l}\text { Very satisfied } \\
\text { Dissatisfied } \\
\text { Neither satisfied nor dissatisfied } \\
\text { Satisfied } \\
\text { Very satisfied }\end{array}$ \\
\hline
\end{tabular}

PICBE $\mid 681$

Source: author's contribution

Patients felt close and understood by all the categories of the medical staff, especially nurses, and then, in decreasing order, by resident doctors, primary doctors and specialists. Regarding the activity of physicians and nurses, the patients were not treated by a preferred doctor, they received clear explanations about the diagnosis but did not receive answers to their questions during the consultation, the majority were prepared preoperatively and prior to the investigations, but have not been given explanations before treatment, which may be a reason for their dissatisfaction.

Patients reported that the psychological support that they received during the internment period was granted by nurses (30\%), by doctors and family (20\%). Only $10 \%$ received the help of a psychologist, while $5 \%$ were helped by priests, friends or other patients in the salon.

Another reason for satisfaction is the $100 \%$ improvement of health status at discharge, and the trust in the services provided by the clinic. Most respondents would recommend the hospital and would return if necessary.

The relationship between emotional intelligence and patient satisfaction - Analysis of statistical indicators

Following the application of the data analysis function of Excel, we calculated the main statistical indicators, the correlation coefficient, and we also made the linear regression to measure the intensity of the link between the variables.

The general tendency towards the central value, the dispersion of the data around it, the minimum, the maximum and the sum of the values obtained by questioning the medical staff for emotional intelligence are summarized in Table 3.3, while Table 3.4 presents the data related to patients' satisfaction. 
Table 3.3 Average arithmetic patient satisfaction

\begin{tabular}{|cc|}
\hline \multicolumn{2}{|c|}{ Total score of IE test } \\
\hline $\begin{array}{c}\text { Mean } \\
\text { Standard Error }\end{array}$ & 4.062839729 \\
Median & 100 \\
Mode & 100 \\
Standard & 20.31419865 \\
Deviation & 412.6666667 \\
Sample & 0.381890429 \\
Variance & 0.001309587 \\
Kurtosis & 90 \\
Skewness & 50 \\
Range & 140 \\
Minimum & 2430 \\
Maximum & 25 \\
Sum & \\
Count & \\
\hline
\end{tabular}

PICBE | 682

Source: author's contribution

$\mathrm{M}=97.2$ is below normal since the interpretation of the emotional intelligence test tells us that between 100 and 125 are average values. Median Me = 100 is equal to the module (the most common value) $\mathrm{Mo}=100$, it is higher than the mean. Standard deviation Dev. $=20,31$ is the size that shows how the mean values of the series deviate from their average, indicating a homogenization of the scores of the tested subjects: $n=25$.

Coefficient of asymmetry Sk. $=0.00$ and the flattening coefficient $K=0.38$ show that the Gaussian distribution is homogeneous over a normal curve. We can also say that this variable admits values between Min. $=50$ and Max. $=140$.

Table 3.4 Presentation of the main statistical indices for patient satisfaction

\begin{tabular}{|cc|}
\hline \multicolumn{2}{|c|}{ Mark for medical services } \\
\hline Mean & 4.24 \\
Standard Error & 0.144684 \\
Median & 4 \\
Mode & 4 \\
Standard & 0.723418 \\
Deviation & 0.523333 \\
Sample & -0.90772 \\
Variance & -0.4054 \\
Kurtosis & 2 \\
Skewness & 3 \\
Range & 5 \\
Minimum & 106 \\
Maximum & 25 \\
Sum & \\
Count & \\
\hline
\end{tabular}

Source: author's contribution

The statistical analysis of the indices of the dependent variable patient satisfaction shown in the notes on hospital medical services leads to the conclusion that there are no major differences in the central trend values. The average score for this dimension is $\mathrm{M}=$ 
4.24 and the $\mathrm{Me}=4$ median equals the Mo $=4$ module, demonstrating that the relatively large values are predominant. We also notice that the scoring of St. Dev. $=0.72$ which shows that there is a homogeneity of the distribution of the scores.

The coefficient of flattening $K=-0,90$ and the asymmetry $\mathrm{Sk}=-0,40$ show a distribution in which the dispersion of the values is small, and the graphical representation would be in the form of a normal curve and slightly elongated to the left. The variable admits values between Min. $=3$ and Max. $=5$.

The statistical analysis of the emotional intelligence variables and patient satisfaction, leads to the conclusion that these values are representative for our study and can be statistically processed to achieve a correlation between the two.

Check hypothesis

To verify the two hypotheses of our study, the correlation coefficient was calculated, the scatter graph and the linear regression were plotted.

Checking the first hypothesis - The correlation of values of emotional intelligence variables and the score for medical services reflecting patient satisfaction is presented in the following table:

Table 3.5 Coefficient of Source Correlation:

\begin{tabular}{|c|r|r|}
\hline \multicolumn{1}{|c|}{} & Total score of IE test & Mark for medical services \\
\hline Total score of IE test & \multicolumn{2}{|c|}{1} \\
Mark for medical services & $\mathbf{0 . 2 1 7 7 5 1 4 6 4}$ & 1 \\
\hline
\end{tabular}

Source: author's contribution

We calculated the correlation coefficient of Pearson $(r=[-1,1])$ which represents a linear relation between the two variables and shows the force of the association between them. The correlation of emotional intelligence with patient satisfaction is positive, the calculated value of the correlation coefficient $r=0.21$ shows that the link is weak according to the interpretation of the Pearson coefficient:

- $r=[0 ; 0,2] \rightarrow$ very poor correlation

- $r=[0.2 ; 0.4] \rightarrow$ poor correlation

- $\mathrm{R}=[0.4 ; 0.6] \rightarrow$ reasonable correlation

- $\mathrm{R}=[0.6 ; 0.8] \rightarrow$ high correlation TEMPLATE

- $r=[0.8 ; 1] \rightarrow$ very high correlation - very close relationship between variables or calculation error

Analysis of the link between the two variables leads to the conclusion that emotional intelligence influences patient satisfaction, which confirms the first hypothesis of this research. 
Checking the second hypothesis - In order to verify the second hypothesis of the study, the correlation between the two variables, namely between emotional intelligence and patient satisfaction, had to be established. Towards this end a scatter chart, also known as " points ", was created, in order to see what is the relationship between the two variables, and how they influence each other. The scatter graph can be seen in Figure 3.1:

Figure 3.1 Scatter chart for the correlation between emotional intelligence and patient satisfaction

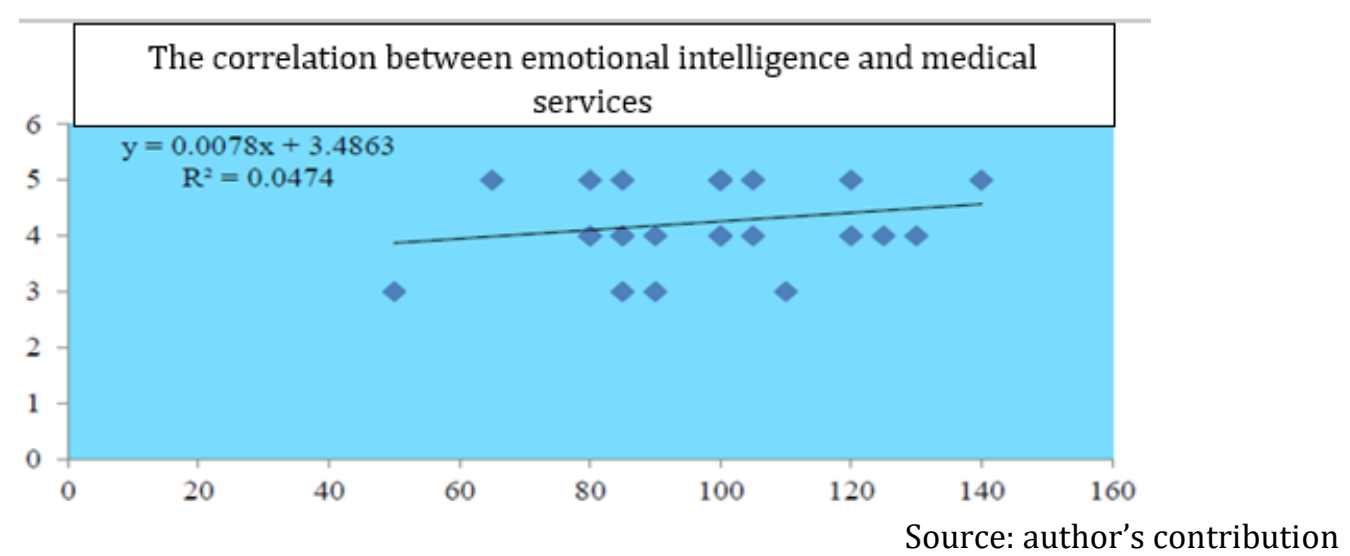

As the chart shows, there is a relationship between the two variables, positive, but very weak, with a small intensity, which is also demonstrated by the scattering of points and the line indicating a similar relation (Liniar Regression, $\mathrm{R}$ Square $=0.04$ ). The Regression Statistics measure shows that there is a weak link between the level of emotional intelligence and patient satisfaction because the correlation ratio is $R=0.21$, with a degree of determination of $4 \%$, the value of this coefficient $\mathrm{R}$ Square $=0.04$, meaning that emotional intelligence influences patient satisfaction by $4 \%$.

In other words, because there is a relationship between the variables studied, the higher the level of emotional intelligence, patient will have a higher satisfaction, thus confirming the second hypothesis of our research.

\section{Conclusions}

Emotional Intelligence has implications with positive results in more and more areas of activity: human resources, management, education, psychology, health, which motivated us in choosing this research theme.

Based on the study we found that patients are generally satisfied with medical services offered $(4,3)$. The level of emotional intelligence of the medical staff is below the average of values $(97,2)$ and influences the satisfaction of the patients, since the correlation between the two variables is positive. This result confirms the theoretical part of the paper. An increased level of emotional intelligence, playing a very important role in the 
relationship between medical staff and patients, would lead to a better quality of medical services provided, and consequently to patients' increased satisfaction, trust and loyalty.

Developing emotional skills so that they benefit from more care and attention to get treatment compliance and desired results is very necessary. The study confirms that in order to increase medical efficiency during treatment and after discharge, specialized emotional intervention (psychologists) should complement medical care, especially in the case of serious illness, as $70 \%$ of patients required psychological support.

Better emotional intelligence, especially empathy, recognition and management of emotions, interpersonal relationships, will make the patient to better overcome fear of disease and to be more cooperative. Therefore, its development must become a priority for the medical staff. Patients should become partners of the medical team, knowledgeable about the medical act due to a good communication, receiving essential information before surgery and during treatment, helped by medical staff to overcome their pain and discomfort in these difficult moments.

While in the medical field employees need to empathize with patients and treat them with special care, the increase in the number of patients treated leads to stress and emotional exhaustion, and to inadequate treatment. A better stress management, and the use of well-being techniques would be very important. The management of the clinic will have to find solutions to motivate staff and increase their optimism, which would lead to greater openness to and greater availability for change, these dimensions of emotional intelligence obtaining the lowest scores in our research.

\section{References}

Andrei, E. (2017). Ordinul MS privind mecanismul de feedback. 10 întrebări la ieșirea din spital. Iată care sunt. Ați răspunde? Textul integral al ordinului. Retrieved on 25.11.2017, from: https://www.ziuaconstanta.ro/informatii/legi-utile/ordinul-msprivind-mecanismul-de-feedback-10-intrebari-la-iesirea-din-spital-iata-care-suntati-raspunde-textul-integral-al-ordinului-620183.html

Bar-On, R. (2006). The BarOn Model of Social and Emotional Intelligence Retrieved on 20.12.2018, from: http://www.eiconsortium.org/reprints/baron_model_of_emotional-social_intelligence.htm

Bradberry, T., \& Greaves, J. (2016). Inteligența emoțională 2.0. București: Litera.

Bratianu, C. \& Orzea, I. (2013). Emotional knowledge: The hidden part of the knowledge iceberg. In Janiunaite, B., Pundziene, A. \& Petraite, M. (Eds). Procedings of the 14th European Conference on Knowledge Management (pp. 82-90), Kaunas University of Technology, Lithuania, 5-6 September 2013. Reading: Academic Conferences and Publishing International.

Buckingam, M., \& Coffman, C. (2014-ed. a III-a). Manager contra curentului. București: ALL. 
Caruso, D., \& Salovey, P. (2012). Inteligența emoțională. București: Business Tech International.

Darwin, C. (1998). The Expression of the Emotions in Man and Animals. New York: Oxford.

Davidson, R., \& Begley, S. (2016). Creierul și inteligența emoțională. Cum îți influențează tiparele lui unice felul în care gandești, simți și trăiești și cum le poți schimba. București: Litera.

Deaconu, A., Podgoreanu, S., \& Rasca, L. (2004). Factorul uman și performanțele organizației [online] www.bibliotecadigitala.ase.ro/biblioteca/carte2.asp?id=370\&idb. Retrieved 12. 3., 2017

Ekman, P. (1993). Facial Expression and Emotion. American Psychologist,48, pp. 384392.

Gardner, H. (1993). Frames of Mind: The theory of Multiple Intelligences. New York: Basic Books.

Goleman, D. (1995). Emotional Intelligence: Why It Can Matter Go More Than IQ For Character, Health and Lifelong Achievement. New York: Bantam Books.

Goleman, D. (1998). Working with Emotional Intelligence. Bloomsburry, UK.

Goleman, D. (2008). Inteligența emoțională. București: Curtea Veche Publishing.

Goleman, D. (2014). Focus: motivația ascunsă a performanței. București: Curtea Veche Publishing.

Goleman, D. (2016). Creierul și inteligența emoțională-Noi perspective-. București: Curtea Veche Publishing.

Goleman, D. (2016). Leadership: puterea inteligenței emoționale: selecție de texte. București: Curtea Veche Publishing.

Goleman, D., McKee, A., \& Boyatzis, R. (2007). Inteligența emoțională în Leadership. București: Curtea Veche.

Hasson, G. (2016). Inteligența emoțională. București: Meteor Publishing.

Salovey, P., Mayer, J.D. (1990). Emotional Intelligence. Retrieved on 20.12.2018, from:http://citeseerx.ist.psu.edu/viewdoc/download?doi=10.1.1.385.4383\&rep=re p1\&type $=$ pdf 